Informatika i sistemy upravleniya. - 2017. - No. 1(51). - P. 15-22.

Devyatisil'nyj A.S. (devyatis@iacp.dvo.ru), Stotsenko A.K.

Institute of Automation and Control Processes

\title{
MODELS OF VEHICLES’ RELATIVE MOTION
}

Prospects of vehicle robotization require more stringent requirements for vehicle motion models, in particular with regard to mechanical precision of describing real vehicles' parameters. In this work, devoted to the analytical design of models controlling linear movement of vehicles, we conducted theoretical and mechanical study of longitudinal motion of a single car and a couple of cars. Here we used a concept of defined motion and studied a vehicle movement relative to the defined movement. The article considers a number of potential models controlling relative motion.

Keywords: motion, velocity, distance, traffic flow, transport unit, control, feedback coupling, mode, constructive mathematics.

DOI: 10.22250/isu.2017.51.15-22

\section{For citation:}

Devyatisil'nyj A.S., Stotsenko A.K. MODELS OF VEHICLES' RELATIVE MOTION // Informatika i sistemy upravleniya. - 2017. - No. 1(51). - P. 15-22. 